\title{
The Determinants of Mergers and Acquisitions: Evidence from Turkey
}

\author{
Aysa Ipek Erdogan \\ Department of Banking and Finance, Okan University \\ Tuzla Kampusu, 34959 Akfirat Tuzla Istanbul, Turkey \\ Tel: 90-216-6771630 E-mail: aysa.erdogan@okan.edu.tr
}

Received: January 14, 2012

Accepted: February 14, $2012 \quad$ Published: April 1, 2012

doi:10.5539/ijef.v4n4p72

URL: http://dx.doi.org/10.5539/ijef.v4n4p72

\begin{abstract}
This study examines the financial variables that predict the merger and acquisition targets in Turkey. Cox regression with segmented time-dependent covariates is used to determine the factors that predict target companies for mergers and acquisitions. The firms that are analyzed are among the top 500 industrial enterprises in Turkey. We find that a lower pretax profit margin is associated with an increased chance of being a merger or an acquisition target. In addition, the lower the debt ratio, the more likely the firm will be a target for a merger or an acquisition.
\end{abstract}

Keywords: Mergers and acquisitions, Targets, Cox regression, Cox proportional hazards model, Turkey

\section{Introduction}

The mergers and acquisitions (M\&As) literature denotes that companies that are targets of M\&As attain significant positive abnormal returns (e.g., Jensen and Ruback, 1983; Huang and Walkling, 1987). Consequently, numerous studies that are motivated to identify target companies establish prediction models for M\&As. The literature considers certain firm characteristics to contribute to being a target company. The size hypothesis argues that smaller firms are more likely to become acquisition targets due to lower costs of absorbing smaller targets into the acquirers' organizational structures (Palepu, 1986; Walter, 1994). The inefficient management hypothesis argues that bidders tend to acquire poorly run firms and benefit from value-enhancing changes (Manne, 1965; Palepu, 1986). Financial leverage hypothesis argue that firms with high unused debt capacity are attractive M\&A targets (Palepu, 1986; Stulz, 1988). The liquidity hypothesis contends that the likelihood of merger increases with an increase in the liquidity of the target because excess liquidity makes it possible for the acquirer to finance the acquisition with the target's own resources. The growth-resources imbalance hypothesis argues that firms with a mismatch between their growth and liquid financial resources provide potential gains to acquiring firms. Asset undervaluation hypothesis argues that firms with low market-to-book ratios are viewed as undervalued and are attractive for M\&As.

Empirical studies that test these hypotheses result in contradictory findings. To our knowledge, there is only one study that examines the financial variables that predict the target companies in Turkey. Ucer (2009) finds that the probability of being acquired increases with an increase in size, financial performance and financial leverage for the firms listed on the Istanbul Stock Exchange. The author provides evidence that is counter to hypotheses regarding size, inefficient management and financial leverage.

This paper contributes to the literature by providing the first attempt to predict M\&A targets in the Turkish context using the financial data of a group of top industrial enterprises. Segmented time-dependent Cox regression model is used to determine the effect of financial variables on M\&As. Results show that a firm faces a higher chance of being a target for a merger or an acquisition with a decrease in its pretax profit margin and debt ratio.

This paper is organized as follows. Section 2 includes a review of the theoretical and empirical literature on the issue of financial characteristics of M\&A targets. Section 3 describes the data and section 4 depicts the research methodology. Section 5 presents the variables. Section 6 discusses the empirical results of the study and section 7 concludes.

\section{Literature Review}

Stevens (1973) argues that acquisitions compete with other capital budgeting decisions for limited funds. Thus, acquisition decisions should be consistent with shareholder wealth maximization criteria and financial characteristics of the targets should be considered in the decision process. The literature presents several firm attributes that are hypothesized to contribute to the possibility of M\&As. It is suggested that size is an important 
explanatory variable in M\&As and smaller companies are more likely to become acquired than larger companies. (Palepu, 1986; Walter, 1994) It is argued that there are several size-related costs of acquisitions. The costs of competition with the other bidders and costs associated with the adaptation of the acquired company to the acquirer's culture can be given as examples for these size-related costs. Size hypothesis is based on the premise that these costs increase with the size of the acquired company and firms acquire smaller firms because size related costs of acquisitions will be lower for them.

Inefficient management hypothesis suggests that inefficiently managed firms whose managers fail to maximize shareholder wealth are more likely to be M\&A targets (Manne, 1965; Palepu, 1986). Brealey and Myers (2010) argue that M\&As are simple and practical ways to improve management.

Financial leverage hypothesis contends that the likelihood of an acquisition increases with a decrease in company debt. Firms with high unused debt capacity are regarded as attractive merger targets because low leverage reduces the risk of default and increases the debt capacity of the joint firm (Palepu, 1986; Stulz, 1988). Low leverage can also trigger a leveraged buyout transaction. Additionally, a low debt ratio can also be seen as a signal of incompetent management and the potential acquirer can hope to increase value by assuming additional debt when control is gained.

Liquidity hypothesis argues that the likelihood of being acquired increases with an increase in liquidity (Song and Walkling, 1993). Cash rich companies are attractive for acquisitions because excess liquidity gives the bidder the opportunity to finance the acquisition with the target's own resources.

The growth-resources imbalance hypothesis submits that firms with a mismatch between their growth opportunities and liquid financial resources are regarded as attractive merger targets (Palepu, 1986). A firm that has growth opportunities, but is cash poor should be an attractive merger target for a company with the reverse features. Conversely, a firm that has limited growth prospects, but has high liquidity should be an attractive merger target for a company with low growth and high liquidity.

Asset undervaluation hypothesis argues that firms with low market-to-book ratios are attractive for acquisitions because they are viewed as undervalued. Hasbrouk (1985) suggests that companies that wish to expand through acquisitions compare the cost of new investment with the cost of acquisition of an existing firm and take the cheaper option.

Empirical studies which generally use discriminant analysis and logistic regression to test the hypotheses of M\&A target attributes show contradictory findings. Monroe and Simkowitz (1971) find that acquired firms were smaller in size in the U.S. However, liquidity and profitability were not important discriminators between acquired and nonacquired firms. Dietrich and Sorenson (1984) also find that the likelihood of being a target is negatively related to size in the U.S. Palepu (1986) provide support for the size, inefficient management, financial leverage and growth-resources imbalance hypotheses. Cudd and Duggal (2000) also provide support for the size hypothesis, the inefficient management hypothesis and the growth-resources imbalance hypothesis for the US. Meador, Church and Rayburn (1996) provide evidence that long-term debt to total assets ratio has a positive effect on M\&As. Agrawal and Jaffe (2003) show that acquired firms do not financially underperform the nonacquired firms in the US.

Camerlynck, Ooghe and Langhe (2001) find that the profitability ratios of acquired companies are higher than industry profitability medians in Belgium. Tsagkanos, Georgopoulus and Siropolis (2006) show that takeover targets are larger and older companies with higher labor productivity and better financial performance in Greece. Hyde (2009) shows that the likelihood of being a target is positively related to profitability, and it is negatively related to size, growth, liquidity and leverage in Australia. Pasiouras, Doumpos and Kosmidou (2004) provide evidence that acquired firms have lower management efficiency and lower leverage than nonacquired firms in Greece. Basu, Dastidar and Chawla (2008) find that bidders acquire targets with lower operating efficiency, larger size, lower leverage and higher liquidity in India.

Brar, Giamouridis and Liodakis (2009) show that firm size is important for takeovers since acquired companies have on average smaller capitalization, lower market share, lower sales and a smaller number of employees than nonacquired companies in Europe. The authors could not find support for the inefficient management hypothesis and financial leverage hypothesis. Pervan, Pervan and Kljaic (2010) show that acquired companies are larger in size than nonacquired companies in Croatia. They also demonstrate lower financial performance.

Barnes (1999) shows that historical accounting data in the UK does not have sufficient predictive ability to identify takeover targets.

To the best of our knowledge, there is only one study that uses financial ratios to distinguish between acquired and non-acquired Turkish firms. The study is done on firms that are listed on the Istanbul Stock Exchange. Ucer (2009) 
finds that acquired firms are larger in size, and they have higher profits than non-acquired firms. The author also shows that target firms are highly leveraged, and the increase in their total debt in the year before acquisition is also higher compared to that of the non-targets. Ucer argues that the acquisition of Turkish firms may be the result of their need for financing.

\section{Data}

Our sample is composed of firms that are among the top 500 industrial enterprises in Turkey. We conduct Cox regression with time-dependent covariates on 37 merged and acquired firms and 173 non-merged and non-acquired firms for the period 2004-2010. The term merger is defined as a transaction in which two companies are combined either by the creation of a new organization or by the absorption of one company by the other. Acquisition is defined as a transaction in which the majority ownership of a firm is acquired.

The distribution of the sample according to industry is presented in Table 1. Table 2 provides the yearly frequency of M\&As.

\section{Research Methodology}

This paper employs the Cox regression with segmented time-dependent covariates as its statistical model. The Cox model is based on a modeling approach to survival data analysis, and it can be used to analyze the effect of several predictor variables on survival (Cox, 1972). The final model from a Cox regression analysis will yield an equation that is similar to that of the multiple regression analysis, except that the dependent variable is the hazard function.

The hazard function is the chance that an individual will experience an event (for example, death) at time $t$, given that the individual has not experienced the event until time $t$. The function is calculated by the division of the number of individuals experiencing the event during the time period starting at $t$ by the number of individuals that has not still experienced the event at the start of time $t$ multiplied by the interval width between times.

The Cox regression model with $\mathrm{k}$ time-dependent covariates is in this form:

$$
h_{i}(\mid \mathrm{z}(\mathrm{t}))=\mathrm{h}_{\mathrm{o}}(t) \cdot \exp \sum_{j=1}^{p} \beta_{j} z_{j}^{i}(t)
$$

where $h_{i}(\mid \mathrm{z}(\mathrm{t}))$ is the time-dependent hazard function for firm i at time t. $z_{j}^{i}(t)$ gives the value of the $\mathrm{j}^{\text {th }}$ covariate at time $\mathrm{t}$ for firm i. $\beta_{j}$ is the corresponding regression coefficient for $z_{j}^{i}(t) . \mathrm{h}_{\mathrm{o}}(t)$ is the baseline hazard at time $\mathrm{t}$ which represents the hazard with all the covariates equal to 0 .

The coefficient for each predictor variable is analyzed to interpret the Cox model. A positive coefficient on a predictor variable implies that the hazard of the event increases with an increase in the predictor variable. A negative coefficient implies that the hazard decreases with an increase in the predictor variable.

Because our M\&As data can be interpreted as survival data, we use the Cox regression with time-dependent covariates to determine the factors that predict M\&A targets. The analysis is conducted by the SPSS 20.0 software package.

\section{The Variables}

The financial variables used in our study are shown in Table 3. Financial data of the firms is provided by Istanbul Chamber of Industry. Data on M\&A cases for publicly-traded firms are provided by Istanbul Stock Exchange. M\&A cases for non-public firms are identified by news search across several news sources. Because our financial variables have different values each year and are not systematically related to time, we define them as segmented time-dependent covariates. We do not include any variable that causes multicollinearity in our estimation. Variance Inflation Factor (VIF) values above 4 indicate multicollinearity. Because none of the independent variables have a VIF value above this cutoff value, there is no problem of multicollinearity in our data.

We test the size hypothesis by using total assets as a proxy for size. Pretax profit margin, return on equity, capital productivity and labor productivity are used as indicators of management efficiency. With these variables, we have the chance to test the inefficient management hypothesis. Financial leverage hypothesis is tested by taking the debt ratio as a covariate. In addition, we look at whether merged and acquired firms and non-merged and non-acquired firms differ in terms of capital intensity and export intensity. Exposure to foreign trade leads to a greater range of experiences and skills acquisition. These experiences and skills gained should lead to a superior level of financial performance. Bidders can acquire firms with a low export intensity and benefit from the value-enhancing changes as the export intensity of the firm is improved. Therefore, we expect to find that a lower export intensity increase the chance of being a target for a merger or an acquisition. 


\section{Empirical Findings}

Table 4 presents the results of our Cox regression analysis. The omnibus tests of model coefficients is significant at the 0.01 level showing that at least one of the covariates significantly contributes to the explanation of duration to event. We have three variables that have significant coefficients. The estimated coefficient for pretax profit margin is statistically significant at the 0.05 level. The coefficient indicates that the lower the pretax profit margin, the more likely that the firm will be a target for a merger or an acquisition. This finding provides partial support for the inefficient management hypothesis which states that acquiring firms prefer poorly run targets. The covariate effect of our other indicators of management efficiency, which are return on equity, capital productivity and labor productivity, cannot be assumed to be different from zero.

The estimated coefficient for export intensity is statistically significant at the 0.05 level. However, the coefficient indicates that export intensity has a minuscule effect on the likelihood that the firm will be a merger or an acquisition target. The estimated coefficient for debt ratio is statistically significant at the 0.10 level. The coefficient shows that a lower debt ratio is associated with an increased chance of being a target for a merger or an acquisition. This finding provides support for the financial leverage hypothesis.

Size and capital intensity do not have statistically significant coefficients. A non-significant coefficient for size shows that we cannot provide support for the size hypothesis.

\section{Conclusions and Limitations of the Study}

The M\&As literature considers certain firm characteristics to contribute to being a target company. Research on the issue of financial characteristics of acquired companies in Turkey is deficient. This study examines the relationship between financial variables and M\&As. Our sample is composed of 37 merged and acquired firms and 173 non-merged and non-acquired firms for the period of 2004-2010. The firms in the sample are among the top 500 industrial enterprises in Turkey. Because our M\&As data can be interpreted as survival data, Cox regression with segmented time-dependent covariates is employed as the statistical model.

We find that the lower pretax profit margin, the more likely that the firm will be a merger or an acquisition target. This finding provides partial support for the inefficient management hypothesis which argues that bidders tend to acquire poorly-run targets to benefit from value-enhancing changes. It also suggests some degree of market discipline for the firms with poor profitability through the threat of a takeover. Our other indicators of management efficiency, which are return on equity, capital productivity and labor productivity, do not have statistically significant coefficients. In addition, we find that the lower the debt ratio, the more likely that the firm will be a merger or an acquisition target. This finding provides support for the financial leverage hypothesis which argues that firms with high unused debt capacity are attractive targets for M\&As.

There are important limitations that must be acknowledged regarding our study. Because of unavailability of data, we cannot test the liquidity hypothesis and the growth-resources imbalance hypothesis. For the same reason, we cannot perform model validation with a holdout sample. Our research is constrained by the limited amount of acquired firms in our sample. Additional research with a larger dataset of acquired firms is required to verify the results. Moreover, this study uses only quantitative variables. Future studies should include qualitative variables that represent nonfinancial characteristics of firms.

\section{References}

Agrawal, A., \& Jaffe, J. F. (2003). Do takeover targets underperform? Evidence from operating and stock returns. Journal of Financial and Quantitative Analysis, 38(4). 721-746. http://dx.doi.org/10.2307/4126741

Barnes, P. (1999). Predicting UK takeover targets: Some methodological issues and empirical study. Review of Qualitative Finance and Accounting, 12 (3). 283-301. http://dx.doi.org/10.1023/A:1008378900054

Basu, D., Dastidar, S.G., \& Chawla, D. (2008). Corporate M\&As in India: Discriminating between bidders and targets. Global Business Review, 9 (2). 207-218. http://dx.doi.org/10.1177/097215090800900203

Brar, G., Giamouridis, M., \& Liodakis, M. (2009). Predicting European takeover targets. European Financial Management, 15(2). 430-450. http://dx.doi.org/10.1111/j.1468-036X.2007.00423.x

Brealey, R., Myers, S., \& Allen, F. (2010). Principles of corporate finance (10 $0^{\text {th }}$ ed.). New York: McGraw-Hill/Irwin.

Camerlynck, J., Ooghe, H., \& Langhe, T. (2001). Pre-acquisition profile of privately held companies involved in take-overs: An empirical study. Small Business Economics, 24(2). 169-186. http://dx.doi.org/10.1007/s11187-003-3807-2

Cox, D. R. (1972). Regression models and life tables (with discussion). Journal of the Royal Statistical Society. Series B 34. 187-220. 
Cudd, M., \& Duggal, R. (2000). Industry distributional characteristics of financial ratios: An acquisition theory application. The Financial Review, 35(1). 105-116. http://dx.doi.org/10.1111/j.1540-6288.2000.tb01409.x

Hasbrouk, J. (1985). The characteristics of takeover targets: Q and other measures. Journal of Banking and Finance, 9(3). 351-362. http://dx.doi.org/10.1016/0378-4266(85)90038-X

Huang, Y., \& Walkling, R. (1987). Target abnormal returns associated with acquisition announcements: Payment, acquisition form, and managerial resistance. Journal of Financial Economics, 19(2). 29-349. http://dx.doi.org/10.1016/0304-405X(87)90008-0

Hyde, C. (2009). Predicting takeover offers in Australia. (Working Paper). Sydney, Australia: MIR Investment.

Jensen, M., \& Ruback, R. S. (1983). The market for corporate control: The scientific evidence. Journal of Financial Economics, 11(1). 5-50. http://dx.doi.org/10.1016/0304-405X(83)90004-1

Manne, H. G. (1965). Mergers and the market for corporate control. The Journal of Political Economy, 73(2). 110-120. http://dx.doi.org/10.1086/259000

Meador, A. L., Church, P. H., \& Rayburn, L. G. (1996). Development of prediction models for horizontal and vertical mergers. Journal of Financial and Strategic Decisions, 9(1). 11-23.

Monroe, R. J., \& Simkowitz, M. A. (1971). Investment characteristics of conglomerate targets: A discriminant analysis. Southern Journal of Business. (November).

Palepu, K.G. (1986). Predicting takeover targets: A methodological and empirical analysis. Journal of Accounting and Economics, 8(1). 3-35. http://dx.doi.org/10.1016/0165-4101(86)90008-X

Pasiouras, F., Doumpos, M., \& Kosmidou, K. (2004). Prediction of acquisition targets in the UK: A multicriteria approach. Operational Research: An International Journal, 4(2). 191-211.

Pervan, I., Pervan, M., \& Kljaic, N. (2010). Financial characteristics of acquired companies - Case of Croatia. The Business Review, 16(1). 163-170.

Song, M. H., \& Walkling, R. A. (1993). The impact of managerial ownership on acquisition attempts and target shareholder wealth. Journal of Financial and Quantitative Analysis, 28(4). 439-457. http://dx.doi.org/10.2307/2331159

Stevens, D. L. (1973). Financial characteristics of merged firms: A multivariate analysis. Journal of Financial and Quantitative Analysis, 8(2). 149-158. http://dx.doi.org/10.2307/2330007

Stulz, R.M. (1988). Managerial control of voting rights: Financing policies and the market for corporate control. Journal of Financial Economics, 20(1-2). 25-54. http://dx.doi.org/10.1016/0304-405X(88)90039-6

Tsagkanos, A., Georgopoulus, A., \& Siropolis, C. (2006). Predicting takeover targets: New evidence from a small open economy. International Research Journal of Finance and Economics, 4. 183-194.

Ucer, S. (2009). Determinants and characteristics of M\&As, and target firm performance: Evidence from Turkey. (Doctoral dissertation, Boğaziçi University, Istanbul, Turkey).

Walter, R. M. (1994). The usefulness of current cost information for identifying takeover targets and earning above-average stock returns. Journal of Accounting, Auditing, and Finance, 9(2). 349-377.

Table 1. Distribution of the sample according to industry

\begin{tabular}{|l|c|}
\hline Industry & Number of Firms \\
\hline Mining and Quarrying & 2 \\
\hline Food, Beverages and Tobacco & 33 \\
\hline Textile, Wearing Apparel, Leather and Shoe & 26 \\
\hline Forest Products and Furniture & 8 \\
\hline Paper, Paper Products and Printing & 8 \\
\hline Chemicals, Petroleum Products, Rubber and Plastic Products & 37 \\
\hline Non-Metal Mineral Products & 23 \\
\hline Basic Metal & 33 \\
\hline Metal Products and Machinery & 23 \\
\hline Automotive & 17 \\
\hline TOTAL & 210 \\
\hline
\end{tabular}


Table 2. Yearly frequency of M\&As

\begin{tabular}{|c|c|c|c|c|c|c|}
\hline 2004 & 2005 & 2006 & 2007 & 2008 & 2009 & 2010 \\
\hline- & 9 & 9 & 8 & 6 & 3 & 2 \\
\hline
\end{tabular}

Table 3. Description of the predictor variables used in Cox regression analysis

\begin{tabular}{|l|l|}
\hline Predictor Variable & Description \\
\hline Pretax Profit Margin & Net Profit before Taxes/Net Sales \\
\hline Return on Equity & Net Profit before Taxes/Stockholders' Equity \\
\hline
\end{tabular}

Table 3. continued

\begin{tabular}{|l|l|}
\hline Capital Productivity & Gross Value Added/Total Assets* \\
\hline Labor Productivity & Gross Value Added / Number of Employees (million TL, 2004 prices*) \\
\hline Size & Total Assets (million TL, 2004 prices**) \\
\hline Capital Intensity & Total Assets/Number of Employees (million TL, 2004 prices*) \\
\hline Export Intensity & Exports/Net Sales \\
\hline Debt Ratio & Total Debt/Total Assets \\
\hline
\end{tabular}

A full set of industry dummies is included.

*Net value added is calculated as the sum of gross wages, paid interest, paid rent and operating surplus.

Gross value added is obtained by adding depreciation and indirect taxes less subsidies to net value added.

**Inflation adjustment is done by calculating the change in wholesale price index, 2003=100)

Table 4. Results of Cox Regression with Segmented Time-Dependent Covariates

\begin{tabular}{|c|c|c|c|}
\hline \multicolumn{4}{|l|}{ Goodness of Fit Measure } \\
\hline & Chi-Square & \multicolumn{2}{|l|}{ Sig. } \\
\hline Omnibus Tests of Model Coefficients & 104,70 & \multicolumn{2}{|l|}{0,000} \\
\hline \multicolumn{4}{|l|}{ Parameter Estimates } \\
\hline & $\mathrm{B}$ & Wald Chi-Square & Sig. \\
\hline Pretax Profit Margin & $-10,32$ & 4,22 & 0,040 \\
\hline Return on Equity & 10,98 & 0,03 & 0,862 \\
\hline Capital Productivity & $-10,80$ & 0,03 & 0,864 \\
\hline Labor Productivity & $-0,00002$ & 0,00 & 0,974 \\
\hline Size & $-0,00000005$ & 0,04 & 0,838 \\
\hline Capital Intensity & $-0,00000001$ & 1,64 & 0,201 \\
\hline Export Intensity & $-0,000013$ & 4,90 & 0,027 \\
\hline Debt Ratio & $-7,67$ & 2,84 & 0,092 \\
\hline
\end{tabular}

